\title{
Polymorphisms rs4673 and rs28714259 in predicting anthracycline-mediated cardiotoxicity in patients with breast cancer
}

\author{
Polymorfismy rs4673 a rs28714259 v predikci antracyklinem \\ zprostředkované kardiotoxicity u pacientek s karcinomem prsu
}

\author{
Gvaldin D. Y., Timoshkina N. N., Vladimirova L. Y., Svetitskaya Y. V., Vaschenko L.S. \\ National Medical Research Center for Oncology, Rostov-on-Don, Russian Federation
}

\begin{abstract}
Summary
Introduction: Against the background of significant progress in anticancer therapy, which makes it possible to improve the quality of life and life expectancy of patients with cancer, anthracycline antibiotics retain their relevance, both for scientific research and for clinical practice. However, the therapeutic efficacy of anthracyclines is associated with the development of various complications, among which the most common is cardiotoxicity. Our study was dedicated to searching for possible associations between rs4673 and rs28714259 single nucleotide polymorphisms (SNPs) and the risk of cardiotoxicity in breast cancer patients who underwent anthracycline-containing chemotherapy. Materials and methods: The study included 256 patients with a diagnosis of breast cancer without diagnosed cardiovascular changes who were treated at the National Medical Research Center of Oncology in Rostov-on-Don in 2019-2020. For SNP genotyping, DNA was extracted from blood and high resolution melting analysis was performed. The presence of SNPs was confirmed by Sanger sequencing. Results: The presence of the T-allele rs 4673 increased the risk of cardiotoxicity in breast cancer patients $6.49 \times(95 \%$ $\mathrm{Cl} 1.48-28.53 ; \mathrm{P}=0.002)$, and the presence of the A-allele rs 28714259 increased the risk $3.27 \times$ $(95 \% \mathrm{Cl} 1.23-8.75 ; \mathrm{P}=0.026)$. For tests based on genotyping rs 4673 and $\mathrm{rs} 28714259$ SNPs, the areas under the receiver operating characteristic (ROC) curves were equal to $71.9 \%$ and $76.3 \%$, respectively. The two-locus SNP-SNP model turned out to be statistically significant: the training balanced accuracy was 0.77 ; similarly, the testing balanced accuracy, and the cross-validation consistency was 10/10. Conclusion: Our study confirmed the predictive value of genetic tests based on the determination of the rs 4673 and rs28714259 SNPs. Genotyping of both SNPs will significantly improve the accuracy of predicting the development of cardiotoxicity against the background of anthracycline-containing therapy and timely identify the risk group of breast cancer patients for whom it is necessary to adjust the therapeutic strategy.
\end{abstract}

\section{Key words}

breast cancer - anthracycline-mediated cardiotoxicity- rs4673 - rs28714259 - SNP-SNP interactions
The authors declare they have no potential conflicts of interest concerning drugs, products, or services used in the study.

Autoři deklarují, že $v$ souvislosti s predmétem studie nemaji žádné komerční zájmy.

The Editorial Board declares that the manuscript met the ICMJE recommendation fo biomedical papers.

Redakční rada potvrzuje, že rukopis práce splnil ICMJE kritéria pro publikace zasílané do biomedicínských časopisů.

Dmitry Y. Gvaldin, PhD

National Medical Research Center for Oncology

14 liniya str., 63

Rostov-on-Don, Rostov region 344037, Russian Federation e-mail:dgvaldin@gmail.com

Submitted/Obdrženo: 18. 5. 2021 Accepted/Príijato: 8. 7. 2021

doi: $10.48095 /$ ccko2021463 


\begin{abstract}
Souhrn
Východiska: Na pozadí významného pokroku v protinádorové terapii, která umožňuje zlepšit kvalitu a délku života pacientů s rakovinou, si antracyklinová antibiotika zachovávají svůj význam, a to jak pro vědecký výzkum, tak pro klinickou praxi. Terapeutická účinnost antracyklinů je však spojena s rozvojem různých komplikací, z nichž nejčastější je kardiotoxicita. Naše studie byla věnována hledání možných asociací mezi polymorfizmy rs4673 a rs28714259 s jedním nukleotidem (single nucleotide polymorphisms - SNPs) a rizikem kardiotoxicity u pacientek s karcinomem prsu, které podstoupily chemoterapii obsahující antracykliny. Materiál a metody: Studie zahrnovala 256 pacientek s diagnózou karcinomu prsu bez diagnostikovaných kardiovaskulárních změn, které byly v letech 2019-2020 léčeny v Národním onkologickém výzkumném centru v Rostově na Donu. Pro genotypizaci SNP byla DNA extrahována z krve a byla provedena analýza tání s vysokým rozlišením. Přítomnost SNP byla potvrzena Sangerovým sekvenováním. Výsledky: Pŕítomnost T-alely rs4673 zvýšila riziko kardiotoxicity u pacientek s karcinomem prsu 6,49× (95\% Cl $1,48-28,53 ; p=0,002)$, a prítomnost A-alely rs28714259 zvýšila riziko $3,27 \times(95 \% \mathrm{Cl} 1,23-8,75 ; \mathrm{p}=0,026)$. U testů založených na genotypizaci rs4673 a rs28714259 SNP byla plocha pod křivkou ROC (receiver operating characteristic) rovna 71,9\%, resp. 76,3\%. Ukázalo se, že model SNP-SNP se dvěma lokusy byl statisticky významný: tréninková vyvážená přesnost byla 0,77, podobně testovací vyvážená přesnost a konzistence křížové validace byla 10/10. Závěr: Naše studie potvrdila prediktivní hodnotu genetických testů na základě stanovení SNPs rs4673 a rs28714259. Genotypizace obou SNPs významně zlepší přesnost předpovědi vývoje kardiotoxicity na pozadí léčby obsahující antracykliny a včas identifikuje rizikovou skupinu pacientek s karcinomem prsu, u kterých je nutné upravit terapeutickou strategii.
\end{abstract}

\title{
Klíčová slova
}

karcinom prsu - antracyklinem zprostředkovanou kardiotoxicita - rs4673 - rs28714259 - interakce SNP-SNP

\section{Introduction}

Anthracyclines (doxorubicin, daunorubicin, epirubicin, idarubicin) form the basis of chemotherapy regimens used to treat acute lymphoblastic leukemia, acute myeloid leukemia, Hodgkin's lymphoma, Ewing's sarcoma, osteosarcoma, neuroblastoma, and breast cancer (BC) [1]. Up to $90-95 \%$ of patients with $B C$ receive anthracycline agents with antitumor efficacy, but their use is associated with the risk of developing anthracycline-mediated cardiotoxicity (AMC), which can subsequently progress to heart failure.

AMC can be acute, subacute, and chronic. At another point, chronic cardiotoxicity is divided into early and late [2]. Acute AMC is rare and reversible. It occurs during anthracycline therapy or within a week after the completion of the last course and manifests itself in the form of temporary arrhythmia, supraventricular tachycardia, pericardial myocarditis and acute left ventricular failure. The acute form of AMC is characterized by a nonspecific ST segment or an abnormality of the T wave on the electrocardiogram [3].

Subacute AMC develops within a few days or weeks after completion of the last course of chemotherapy and proceeds in the form of acute heart failure, myocarditis and pericarditis [4].

Early chronic AMC occurs within a year after the end of anthracycline therapy. It is characterized by systolic or diastolic ventricular dysfunction with the development of dilated cardiomyopathy and a decrease in the mass and wall of the left ventricle.

Late chronic cardiotoxicity takes the form of cardiac dysfunction. A distinctive feature of late chronic AOC is its asymptomaticity for a long period, followed by dilated and restrictive cardiomyopathy and, ultimately, the development of congestive heart failure.

Analysis of literature data [5] and own preliminary research [6] made it possible to select two single nucleotide polymorphisms (SNPs) associated with the development of pathological conditions of the cardiovascular system and potentially with the risk of AMC.

In this study, we determined the features of the distribution of rs4673 and rs28714259 SNPs in patients receiving anthracycline-containing therapy for $\mathrm{BC}$, depending on the severity of complications from the cardiovascular system, in order to assess the possible association of markers with the risk of early AMC.

\section{Material and methods}

The study included 256 patients of the Caucasian type (median age 50 years, range 22-71 years) with a diagnosis of BC without diagnosed cardiovascular changes who were treated at the $\mathrm{Na}$ tional Medical Research Center of Oncology in 2019-2020. All patients were shown to carry out 4 cycles of chemotherapy with anthracycline antibiotics according to the AC scheme: doxorubicin $60 \mathrm{mg} / \mathrm{m}^{2}+$ cyclophosphamide $600 \mathrm{mg} / \mathrm{m}^{2}$ per day every 3 weeks. For SNP genotyping, DNA was extracted from blood and high resolution melting analysis was performed. The presence of polymorphisms was confirmed by Sanger sequencing. Statistical analysis of alleles and genotypes was performed using the SNPassoc package in the R 4.0.3 software environment [7]. One-way analysis of the odds ratio (OR) was performed using contingency tables. The null statistical hypothesis of no difference was rejected at a cut-off level of $P<0.05$. The prognostic efficiency of markers was assessed using the receiver operating characteristic (ROC) analysis and the "pROC" package [8]. The analysis of SNP-SNP interactions was performed using the GMDR v.0.9 program [9].

\section{Results}

According to the results of the examination, taking of anamnesis, instrumental research methods - electrocardiography and echocardiography - carried out before the start of chemotherapy courses, the patients were divided into two groups: group 1 (235 patients) without diagnosed cardiovascular changes and group 2 (21 patients) with subacute and early chronic forms of cardiotoxicity (Tab. 1). 
Tab. 1. Clinical characteristics of patients with breast cancer undergoing anthracycline-containing therapy.

\section{Clinical parameters}

LVEF before starting chemotherapy, median (range)

LVEF after 4 cycles of chemotherapy, median (range)

LVEF after 3 months from chemotherapy, median (range)

ECG abnormalities

arrhythmia

cardialgia

pronounced dyspnoea

\section{Group 1}

$65(58-75)$

$64.5(58-77)$

$64.5(58-76)$

$0 \%$

$0 \%$

$0 \%$

$0 \%$
Group 2

$66(60-71)$

$62(56-65)$

$55(46-61)$

$33.3 \%$

$52.4 \%$

$42.9 \%$

$85.7 \%$

ECG - electrocardiography, LVEF - left ventricular ejection fraction
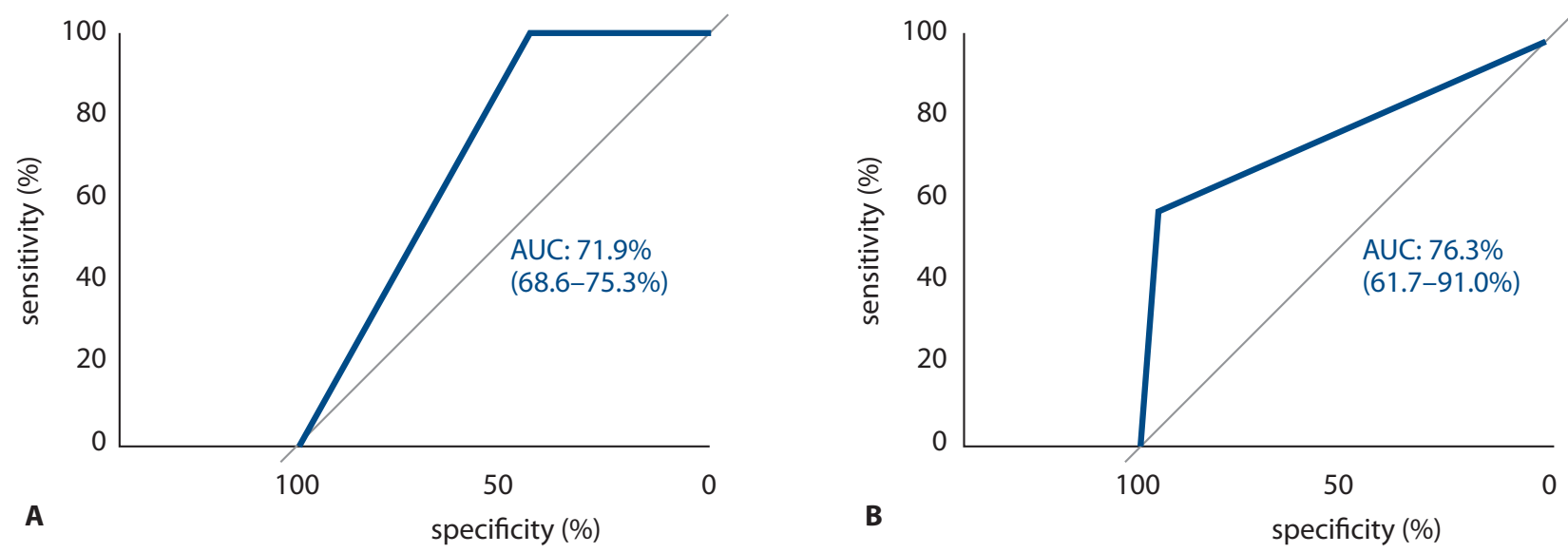

Fig. 1. The receiver operating characteristic $(\mathrm{ROC})$ curves of models for predicting the risk of developing anthracycline mediated cardiotoxicity: A) dominant model rs4673 (CYBA); B) dominant model rs28714259.

In the first group, there were no significant differences between the baseline value of left ventricular ejection fraction (LVEF) and LVEF after the $4^{\text {th }}$ course, as well as between the baseline value of LVEF and LVEF after 3 months from the end of chemotherapy. In the second group, LVEF decreased after 4 courses of chemotherapy by $4 \%$ compared to the baseline value $(P=0.001)$. An even greater decrease in this parameter was observed after the completion of chemotherapy, by $11 \%$ lower than the baseline value $(P<0.001)$. Before chemotherapy, there was no significant difference in LVEF between the two groups, and similarly, nor after 4 cycles of chemotherapy. Expectedly, LVEF was significantly lower in the group of patients with AMC compared with patients without cardio- vascular complications both after the $4^{\text {th }}$ cycle and after the completion of chemotherapy cycles.

According to the data obtained in the course of univariate analysis, the risk of cardiovascular changes during anthracycline therapy increased in carriers of the $\mathrm{C} / \mathrm{T}$ and $\mathrm{T} / \mathrm{T}$ genotypes at the rs4673 locus $6.49 \times(95 \% \mathrm{Cl} 1.48-28.53$; $P=0.002)$, in the case of the $G / A$ and $A / A$ genotypes at the rs28714259 locus, the increase was $3.27 \times(95 \% \mathrm{Cl} 1.23-8.75$; $P=0.002)$. The results of the ROC analysis testified to the high quality of the tests based on the dominant models rs4673 and rs28714259. In the first case, the AUC was $71.9 \%$, in the second one $76.3 \%$ (Fig. 1).

We have identified the associations between the presence of polymor- phic alleles rs28714259 and rs4673 and the decrease in LVEF in patients with breast cancer after 3 months from the end of chemotherapy. The presence of rs28714259, both in the heterozygous and homozygous states, increased the likelihood of impaired left ventricular contractility $6.6 \times(95 \% \mathrm{Cl} 1.92-22.75$; $\mathrm{P}=0.003)$ after the end of chemotherapy, the presence of rs4673 allele $3.68 \times$ (95\% Cl 0.95-14.16; $\mathrm{P}=0.039$ ).

In the study of SNP-SNP interactions, the two-locus model turned out to be statistically significant: the training balanced accuracy was 0.7707 , the testing balanced accuracy was similar, and the cross-validation consistency was $10 / 10(P=0.011)$. It was found that the highest risk of AMC was due to the combination of genotypes $\mathrm{G} / \mathrm{A}$ 
rs28714259 and C/T or T/T rs4673 (odds ratio $(\mathrm{OR})=9.77,95 \% \mathrm{Cl} 1.78-53.78)$.

\section{Discussion}

Despite the fact that the antitumor efficacy of anthracycline antibiotics has long been known, the mechanisms underlying their cardiotoxicity remain unclear. It is assumed that this pathology is a complex multifactorial process that can be caused by oxidative stress and lipid peroxidation, impaired calcium homeostasis, inhibition of autophagy and apoptosis [10].

The CYBA gene is located on the long arm of chromosome 16 and encodes the light alpha subunit of NADPH-oxidase. The rs4673 (c.214T>C) polymorphism of the CYBA gene in exon 4 causes changes in the secondary structure and functions of the encoded protein [11]. The information about the role of this SNP in predicting AMC is rather contradictory. Wojnowski et al found that the presence of the rs4673 polymorphic allele increases the risk of AMC $2 \times(95 \% \mathrm{Cl}$ 1.3-5) [12]. Interestingly, in the study of Cascales et al, rs4673 had a cardioprotective effect and reduced the likelihood of focal myocardial necrosis in patients with various cancers on anthracycline chemotherapy [13].

SNP rs28714259 (g.23463380G >A) is located in the noncoding region of chromosome 15 . This region interacts with other distant elements of the genome and is involved in the regulation of the signaling pathway of glucocorticoids [14]. It is known that signaling by glucocorticoids plays a key role in the formation of the heart muscle at the stage of embryogenesis and the maintenance of its functional activity in various model animals [15]. The role of rs28714259 in predicting the risk of AMC is limited to the study of Schneider et al [14]. The authors reported an increase $(O R=1.9 ; P=0.04)$ in the risk of chronic heart failure in patients with breast cancer who underwent anthracycline chemotherapy cycles [14].

According to the recommendations of the American Society of Clinical Oncology (ASCO), the American Society of Echocardiography (ASE), the European Association of Cardiovascular Imaging (EACVI), LVEF should be assessed over time during cycles of anthracycline-containing chemotherapy to prevent possible cardiovascular disorders. The European Society for Medical Oncology (ESMO) has presented an algorithm for monitoring and managing patients undergoing potentially cardiotoxic anticancer therapy. So according to this approach, a decrease in LVEF by more than $10 \%$ is the reason for the temporary withholding of anthracycline-containing chemotherapy and the use of cardiovascular agents to normalize cardiac function. The results of our study indicated a strong association between polymorphisms and a decrease in LVEF in patients with breast cancer after 3 months from the end of chemotherapy. The genotyping of these polymorphisms can significantly complement the developed approach and add a prognostic stage to assess the risk of possible cardiovascular complications.

\section{Conclusion}

Our study confirmed the predictive value of genetic tests based on the determination of the rs4673 and rs28714259 SNPs. Genotyping of both SNPs will significantly improve the accuracy of predicting the development of cardiotoxicity against the background of anthracycline-containing therapy and timely identify the risk group of breast cancer patients for whom it is necessary to adjust the therapeutic strategy. The findings may be relevant for other malignant neoplasms in which anthracycline-containing therapy is used.

\section{References}

1. Bhatia S. Genetics of anthracycline cardiomyopathy in cancer survivors: JACC: CardioOncology State-of-theArt Review. JACC CardioOncol 2020; 2(4): 539-552. doi: 10.1016/j.jaccao.2020.09.006.

2. Cai F, Luis MAF, Lin $\mathrm{X}$ et al. Anthracycline-induced cardiotoxicity in the chemotherapy treatment of breast cancer: preventive strategies and treatment. Mol Clin Oncol 2019: 11(1): 15-23. doi: 10.3892/mco.2019.1854.

3. Horacek JM, Jakl M, Horackova J et al. Assessment of anthracycline-induced cardiotoxicity with electrocardiography. Exp Oncol 2009; 31(2): 115-117.

4. Manrique CR, Park M, Tiwari N et al. Diagnostic strategies for early recognition of cancer therapeutics-related cardiac dysfunction. Clin Med Insights Cardiol 2017; 11: 1179546817697983. doi: 10.1177/1179546817697983.

5. Kit OI, Gvaldin DY, Omelchuk EP et al. Current views on predictors and biomarkers of early diagnosis of anthracycline-mediated cardiotoxicity in patients with breast cancer (review of literature). Klin Lab Diagn 2020; 65(3): 141 148. doi: 10.18821/0869-2084-2020-65-3-141-148.

6. Gvaldin DY, Timoshkina NN, Omelchuk EP et al. Association of rs 28714259 polymorphism with a risk of early-onset chronic anthracycline-mediated cardiotoxicity in patients with breast cancer. J Clin Oncol 2020; 38 (suppl 15). doi: 10.1200/JCO.2020.38.15_suppl.e13504.

7. González JR, Armengol L, Solé $X$ et al. SNPassoc: an R package to perform whole genome association studies. Bioinformatics 2007; 23(5): 644-645. doi: 10.1093/bioinf ormatics/btm025

8. Robin X, Turck N, Hainard A et al. pROC: an open-source package for R and S+ to analyze and compare ROC curves. BMC Bioinformatics 2011; 12: 77. doi: 10.1186/1471-2105$12-77$

9. Chen GB, Xu Y, Xu HM et al. Practical and theoretical considerations in study design for detecting gene-gene interactions using MDR and GMDR approaches. PLoS One 2011; 6(2): e16981. doi:10.1371/journal.pone.0016981.

10. Songbo $M$, Lang $H$, Xinyong $C$ et al. Oxidative stress injury in doxorubicin-induced cardiotoxicity. Toxicol Lett 2019; 307: 41-48. doi: 10.1016/j.toxlet.2019.02.013.

11. Mazaheri M, Karimian M, Behjati M et al. Association analysis of rs 1049255 and rs4673 transitions in p22phox gene with coronary artery disease: a case-control study and a computational analysis. Ir J Med Sci 2017; 186(4): 921-928. doi: 10.1007/s11845-017-1601-4.

12. Wojnowski L, Kulle B, Schirmer M et al. NAD(P)H oxidase and multidrug resistance protein genetic polymorphisms are associated with doxorubicin-induced cardiotoxicity. Circulation 2005; 112(24): 3754-3762. doi: 10.1161/CIRCULATIONAHA.105.576850

13. Cascales A, Pastor-Quirante F, Sánchez-Vega B et al. Association of anthracycline-related cardiac histological lesions with NADPH oxidase functional polymorphisms. Oncologist 2013: 18(4): 446-453. doi: 10.1634/theoncologist.2012-0239. 14. Schneider BP, Shen F, Gardner L et al. Genome-wide association study for anthracycline-induced congestive heart failure. Clin Cancer Res 2017; 23(1): 43-51. doi: 10.1158/1078-0432.CCR-16-0908

15. Rog-Zielinska EA, Thomson A, Kenyon CJ et al. Glucocorticoid receptor is required for foetal heart maturation. Hum Mol Genet 2013; 22(16): 3269-3282. doi: 10.1093/hmg/ddt182 